\title{
Despite dislocations: Uganda's Indians remaking home ${ }^{1}$
}

\author{
Savita Nair
}

Human experience moves in spaces that we grossly distort by merely drawing routes of trade, migration, and cultural flows among territories defined only by national maps. (Ludden 2003: 1069)

In April 2007, Devang Rawal, a young man originally from India, ${ }^{2}$ was killed in Kampala, Uganda, during riots protesting against plans by the Sugar Corporation of Uganda to expand its estates into the Mabira rainforest, one of the few protected natural forests in Uganda. The conflict between the Sugar Corporation and the local residents and environmental activists hinged on a proposed government study on whether to cut down nearly a third of the Mabira forest. The company proposed that the economic benefits of the plantation, including the creation of jobs in sugar production, far outweighed the environmental costs. Protestors disagreed, ostensibly for environmental reasons and due to the cultural significance of sacred forest spaces, but also out of what were seen as anti-Indian sentiments. The Sugar Corporation of Uganda is owned by one of Kampala's longest-standing and most prominent Indian business families, the Mehtas. Protestors used handwritten placards to express their objections and the severity of the consequences should their demands not be met. One banner read ' 1 Tree Cut $=5$ Indians Killed'.

The 'Save Mabira' crusade began as a peaceful march from Kampala to the Mabira forest; demonstrators included local politicians, environmentalists, and civic groups including local Buganda (non-Indian) communities (Mutabazi n.d.). However, when campaigners and police confronted each other, and mobs started to form, peace and order disappeared and there were riots including attacks near a Hindu temple and directed at Indian-owned businesses. The Ugandan government

\footnotetext{
Savita Nair is Associate Professor in the Department of History and the Department of Asian Studies at Furman University (Greenville, South Carolina). She studies the Indian diaspora, particularly nineteenth- and twentieth-century migrant networks between India and Eastern Africa. Email: savita.nair@furman.edu

${ }^{1}$ This article focuses only on Kampala and Jinja in Uganda, and Porbandar and Ahmedabad in the western Indian state of Gujarat.

The 1969 census numbered the Asian population in Uganda at about 70,000. Asians were officially considered foreigners despite the fact that more than $50 \%$ of them had been born in Uganda. By the 1970s South Asians had gained control of the retail and wholesale trade, cotton ginning, coffee and sugar processing, and other segments of commerce. President Amin deported about 70,000 Asians in 1972, and only a few returned to Uganda in the 1980s to claim compensation for their expropriated land, buildings, factories, and estates. In 1989 the Asian population in Uganda was estimated at only about 10,000. (<http://www. africa.upenn.edu/NEH/u-ethn.html>, accessed 11 May 2015)

Over 15,000 of those expelled returned to reclaim properties (Selva 2005).

${ }^{2}$ Rawal was from the city of Ahmedabad, the commercial capital of Gujarat state in western India.
} 
deployed troops to control the protests since the local police seemed unable to subdue the attacks. Three people were killed and Indian businesses were vandalized. Stores remained closed for days. Rawal had planned to return to India the next month to get married; ${ }^{3}$ instead, his body was flown back to Ahmedabad for funeral rites. As an Indian citizen who had worked for an import firm in Uganda for two years, Rawal represented the newest wave of migration from India to Uganda, which started in the early 1990s. ${ }^{4}$ As such, he joined an estimated 15,000 South Asians living in Uganda by 2005. Yet this number is a far cry from the over 90,000 Indians who lived in Uganda in 1972, prior to President Idi Amin's call for their expulsion. The events of April 2007 were hauntingly familiar not only to the repatriated, previously expelled Indians, but also to the governments of India and Uganda. New Delhi and Entebbe, and Ahmedabad and Kampala, were alight with official statements, assurances, regret and condolences; journalists interviewed family members of the deceased and injured, the protestors, government officials, Indian store owners and Ugandan bystanders.

Nanji Kalidas Mehta, the company founder, was one of the earliest entrepreneurs and foremost Indian pioneers in Uganda (Nair 2001). ${ }^{5}$ N. K. Mehta made a home in Uganda at the start of the twentieth century, and his son Mahendra, who is the head of the Mehta Group, which runs the Sugar Corporation of Uganda, continues to do so; Devang Rawal was among the most recent group of Indians attempting to succeed in a similar manner. The year 2007, like 1972 - and like 1927 and 1897 before them - marks a moment when Indians in Uganda came under xenophobic assault, and India and Uganda became further intertwined with one another. ${ }^{6}$

Rawal's tragic ending reveals a much older and more complex tale of Uganda Indians which placed India and Uganda within the same historical frame. This historical frame includes: (1) the Mehta family's century of crisscrossing between western India and East Africa; (2) the expulsion and return to India of Indians in the 1970s; and (3) the Indians who repatriated to Uganda in the 1990s. My project supports a perspective connecting lived experience with history, joining

\footnotetext{
${ }^{3}$ 'Protect Indians in Uganda, says Congress', The Hindu, 16 April $2007<$ http://www.thehindu. com/todays-paper/tp-national/protect-indians-in-uganda-says-congress/article1829244.ece>, accessed 11 May 2015.

4'Uganda promises Indians security', Hindustan Times, 13 April $2007<$ https://www.hindustantimes.com/india/uganda-promises-security-to-indians/story-Q9UooxlhW6W4smtw2yChdK. html>; 'Amin redux: Indians killed in Uganda attack', Hindustan Times, 14 April 2007 <http:// www.lexisnexis.com.libproxy.furman.edu/hottopics/lnacademic/?shr=t\&csi $=282802 \& \mathrm{sr}=\% 28 \%$ 22Amin $\% 20$ redux:\%20Indian $\% 20$ killed $\% 20$ in $\% 20$ Uganda $\% 20$ attack $\% 22 \% 29+$ AND+DATE +IS+2007>, both accessed 11 May 2015.

${ }^{5}$ In 'Moving life histories' (Nair 2001), I argue that the life histories of Mehta family members serve as evidence that East Africa Indians participated in and created a major historical region not bound by political borders or geographic circumstance, although it was deeply enmeshed in geopolitics. My 2001 thesis adds to the now burgeoning scholarship on the Indian Ocean littoral.

${ }^{6}$ The expulsion of Indians from Uganda occurred in 1972. In 1927, and in the 1920s more generally, the demands of the East African National Congress sparked lively debate in Kampala, and elsewhere in East Africa, in Mumbai, Delhi and London. In 1897, the British imported Indian labourers who began working on the British East African Uganda Railway, eventually connecting the coast to Lake Victoria. A total of 30,000 indentured labourers were brought from India to East Africa. Independent entrepreneurs and professionals from India followed them, seeking economic opportunities in this burgeoning colonial site.
} 
other scholars with diverse geographic foci who have argued for this (Benmayor and Skotnes 1994; Cohen 1995; Lucassen and Lucassen 1997; Moch 1992), and calls for scholars of the South Asian diaspora to take seriously the importance of region (Markovits 2000) for those participating in this 'entrepreneurial diaspora' (Reeves 2006).

The life histories ${ }^{7}$ of diverse Indian migrants reveal the reciprocal memory-making between India and Uganda: multiple imaginings of 'home', their transformed identity as Uganda Indians, and their memories of displacement. These recollections, of course, are transitory and are riddled with the emotions the authors experienced when they wrote or spoke about them. This means that they are not necessarily a perfect historical record of the events as they occurred. People tell stories about their experiences and these narratives create a sense of place and identity. However, what do we do when the narrative is disrupted? Changing the narrative of their identity as outcasts is not sufficient when these so-called outcasts (or refugees) have returned to their 'homeland'. We experience and remember our world through narrative, and these stories express emotion in how we think of ourselves (Worth 2017). Memory works in a way that is fragile and fractured, and, in the case of the diverse migration narratives I discuss here, is clung to tightly.

Untold and undocumented narratives of two Indian neighbourhoods of refugees, as well as of new or renewed migration, confirm the need for creative approaches to best understand the identities of these migrants in a way that is not possible through studying either origin or destination sites. These neighbourhoods are memorials to expulsion; their residents are the weary bricks supporting the memorials, their memories serving as mortar. By tracing various movements across continents, I examine the fault lines for Indian migrants in terms of their identity, investment in and interaction with East Africa and with India. I draw on newspaper reports, local and colonial documents, and oral historical sources in India and Uganda in order to highlight the centrality of migrants and, by doing so, to place India and Africa in the same intellectual and interactive space. Uganda Indians must be understood in their varied and circular configurations; the different reasons, time periods and political contexts of each migration, expulsion and return provide an insight into the lived experience and self-defined identity of these migrants. Given these rich contextual understandings, how does a place of origin or an autobiography ${ }^{8}$ - 'memory-speaking' - become a site for memorializing diasporic identity? How do memories of rejection and return factor into (multi)national loyalties, notions of home and diaspora identities?

Situated in the context of renewed interest in contemporary migration, diaspora studies and the deterritorialization of history writing, ${ }^{9}$ the multiple and circular

\footnotetext{
${ }^{7}$ I have collected most of these life histories through interviews with Uganda Indian families in India and in Uganda. N. K. Mehta's story comes in part from his autobiography but also through additional oral historical work with his descendants.

${ }^{8}$ Precisely because the autobiography mentioned in this article connects the writer's own time and later interventions by his children or minimally joint reminiscences and named translators (Desai 2011; Ojwang 2012), the autobiography is a collectively motivated representation of the past. In this case, it is about how the father wanted his legacy to be remembered and how the children wanted to remember their father.

${ }^{9}$ For South Asia studies, early proponents included, but are not limited to, Peter van der Veer (1995), Arjun Appadurai (1996) and David Ludden (2002).
} 
migrations of Gujarati families in East Africa offer new ways to conceptualize 'place', those who inhabit such spaces, and how they remember and define their own diaspora identities. Scholarly work on the Indian merchant networks in the Indian Ocean began to flourish a few decades ago, with formative big-picture work by K. N. Chaudhuri (1985), Ashin Das Gupta (1987), Michael Pearson (2003) and Claude Markovits (2000), and important ethnographies of intraregional merchant networks by David Rudner (1994), to name but a few examples. More recent work has expanded the scope to poetically complicate globalization and the nation (Bose 2006); to consider trans-coastal connections without British orchestration (Metcalf 2008); to include popular culture exchanges and hybridities (Alpers 2013); to consider language and religion in addition to labour (Sheriff and Ho 2014); to update and expand the oceanic framework narrative (Machado 2014, Freitag 2011; Allen 1981); and to consider the hajj and merchant transactions (Mishra 2011). I am particularly aligned with work that considers migrants who were often not part of the surveillance and official recording endeavours of British officials: that is, those laissez-faire merchant-adventurers, such as N. K. Mehta, who remained hidden from the official and scholarly record and thus force us to develop new questions and methodologies to tap into their histories (Anderson 2012).

Families are not stationary; they move, circularly (Markovits 2000: 4), and they bring institutions, policies, capital, ideas and histories with them. The notion of home, too, is thus mobile and multiple, characterized by what has been described as the "dialectics of "belonging" and "longing"" (van der Veer 1995: 4) and by negotiations between 'the metaphorical and the physical home' (Agnew 2005: 4-5). Such 'longing and belonging' require attention to memories of what is being longed for and a community's memories of belonging, of acceptance or hostility, or of expulsion followed by a later invitation to repatriate. For Uganda Indians, like those in other sites in the vast South Asian diaspora, the last hundred years have proved to be traumatic, dissonant and supremely complex. Forced expulsion is high on the 'trauma' scale. East Africa and India became lands alive with family life, commercial pursuits and political stakes, even though the historical records of the two places do not consistently include the people who called these places home in the national imagination. ${ }^{10}$ For Uganda Indians, their history is laden with memories of success and distress as well as amnesia about achievements and ordeals. For example, this point is demonstrated by N. K. Mehta's story about when he decided to invest in developing Kampala and Jinja (Uganda) as well as in Porbandar (India) in the early to mid-twentieth century. It is also illustrated by his son, Mahendra, who withdrew his interest in acquiring the Mabira forests in the wake of the 2007 protests in Uganda following pressure from Uganda Indians - both those previously expelled and then repatriated and new entrepreneurial arrivals.

\footnotetext{
${ }^{10}$ To some extent, this continues to be a debatable issue, even following the formation of the government's Ministry of Overseas Indian Affairs and events linked to the recent India Diaspora Day (Pravasi Bharatiya Divas). Even Prime Minister Nehru opted not to intervene in many cases of Indian persecution abroad, stating that they were matters between Indians and their new states of residence, particularly when citizenship was relinquished - notably in Burma.
} 
As the primary historical actors in my research, Uganda Indians fall under multiple categories of migration history: (1) those who migrated to Uganda in the late nineteenth and early twentieth centuries, such as N. K. Mehta; (2) those who were expelled from Uganda in 1972 and then returned to India as refugees in two superficially distinct neighbourhoods in Ahmedabad (Gujarat) following the Indian government's resettlement scheme for Uganda Indian refugees; ${ }^{11}$ and (3) those expelled who returned to Uganda in the 1990s after the Government of Uganda's 'repossession of properties' policies. ${ }^{12}$ The post-1972 expulsion predicaments of migration help complete the story of over a century of migration, memories, remittances and reintegration.

Diasporic life histories, even when disrupted by expulsion, place Kampala and Ahmedabad, for example, within a single frame. Thus, rethinking the historical geography of India and Uganda (and Britain) makes western India's overseas constituents central rather than marginal to discussions about Indian history, Ugandan history, the politics of regional/nationalized identities, and ideas of home. For example, the Mehta family, as well as the Mehta Group - the contemporary inheritor of Mehta's commercial and familial legacy - have framed the collective memory of a community.

In what follows I complicate the standard narratives ${ }^{13}$ that have been reproduced by the collective memory of Uganda's expelled Indians. Standard accounts of Indian or Ugandan history rarely include those who left or those who arrived, thus leaving migrants liminal in the histories of places that they consider vital to their sense of identity, those places for which they long and to which they seek to belong, and the homes through which they circulate. I argue that such an omission masks the facts of history, obscures overlapping collective identities, and ignores the ways in which space and time are reflected in individual and community memories. I will show, for example, that an examination of the Mehta family's construction of memory sites in Gujarat and the Indian government's construction of two distinct Gujarati refugee resettlement neighbourhoods helps remedy oversimplified understandings of migration. Narratives of mobility and circular mobility challenge the assumed metanarrative; however, much of the written work in the immediate aftermath of the 1972 expulsion appeared defensive and apologist ${ }^{14}$ or denied the role of the Government of India in assisting repatriates in the early 1970s. ${ }^{15}$ The desire to display India's 'contribution' and 'philanthropy' was

\footnotetext{
${ }^{11}$ Primary written material and oral historical sources supplement a basic survey of secondary sources. By focusing on Ahmedabad and not Kheda district in Gujarat, where many repatriates returned, my argument is specific to urban rather than rural areas in both countries. Deeper and broader investigation into the factors noted here are needed for more conclusive explanations; however, this is a start.

${ }^{12}$ The primary policies were the 1983 Repossession Scheme and the 1992 Act to Repossess Properties (Nair 2007). Between 1991 and 1996, the first five years after the Ugandan government's repatriation schemes were announced, there were close to 2,000 properties repossessed and returned to their original Indian owners (Obwona n.d.).

${ }^{13}$ Mahmood Mamdani $(1976 ; 2011)$ and Michael Twaddle (1975) have written about the Uganda Indians' expulsion in ways that have greatly benefited my understanding. I also am grateful for Robert Gregory's foundational early work, India and East Africa: a history of race relations within the British Empire (1971).

${ }^{14}$ See work by Robert Gregory (1971; 1992; 1993) and R. R. Ramchandani (1980).

${ }^{15}$ This includes both journalistic accounts and scholarly work in the 1970 s about the expulsion.
} 
pervasive. Late nineteenth- and early twentieth-century Indian migration to East Africa enables me to re-ascribe meaning to political regions and states, and to otherwise circumscribed notions of space. ${ }^{16}$ Regions rather than nations represent homelands for migrants in part because it is the region that defines how they remember their lives and the spaces they consider meaningful. The examples of the Mehta family and residents of the two neighbourhoods make it clear that memories of home are not circumscribed by nation states, and meaningful spaces are not defined by governing bodies or by a community of others. The ability of a region ${ }^{17}$ to participate in histories that escape the nation therefore rescues mobility as a constituent feature of South Asian history (Ludden 2003). ${ }^{18}$

\section{The Mehtas: Uganda sugar cementing India}

For Nanji Kalidas Mehta, who represents the first wave of Indian entrepreneurs to Africa, migration to East Africa was a voyage of adventure and of circumstance. Born in 1888 in the village of Gorana, Gujarat, twelve-year-old Mehta left his groundnut farming community to accompany his cousin who was returning to Africa. ${ }^{19}$ Mehta left the port of Porbandar and arrived in East Africa on 17 January 1901 (Mehta 1987: 30). Porbandar has a long history of being one of western India's most active port towns, especially for trade in the Indian Ocean, ${ }^{20}$ although it no longer has the extensive port traffic that it once did. Mehta first worked as a cook for his cousin and then as a business assistant in his shop. Mehta returned regularly to India and travelled to various South and East African towns, where he worked as an accountant for family members. ${ }^{21}$

Mehta's autobiography serves as a repository for his memories of East Africa and his longing for what India and East Africa could become by working towards common goals. He attempted, with various degrees of success, to live out his idealistic vision of a unified India and Africa. I argue that Dream Half-

\footnotetext{
${ }^{16}$ In a larger project, I have argued that, for South Asian history and the diaspora, cultural and social identities in motion across borders have become imprisoned by nationality as it appears on passports stamped at those borders (Nair 2001).

${ }^{17}$ In this case, the region is the north-western Arabian Sea zone, which encompasses Uganda and Gujarat.

${ }^{18}$ Mobility is also a critical feature of East African history, as the area has a millennia-old history of trade and mobile communities across and throughout the Arabian Sea oecumene, spreading goods, people, language, food and religion, among other things.

${ }^{19}$ Mehta was from a family of Gujarati Hindus (from what is now the state of Gujarat) and was part of the Lohana (merchant) community. The village of Gorana is primarily a groundnut (peanut) farming community. Mehta's uncle had been the first to go across the Indian Ocean and set up a shop in Madagascar. Like others, Mehta left for East Africa knowing that he had a contact. He left from the port of Porbandar in the western state of Gujarat and travelled to Bombay and then to Mombasa on a twenty-six-day, 2,400-mile journey on a dhow (a wooden sailing boat that was used for travel across the Indian Ocean before steamships, and later as a less expensive alternative to steamship travel). Dhows continue to be built in Porbandar although they now serve primarily as fishing vessels.

${ }^{20}$ As Surat (Gujarat) declined as a major port during the mid-eighteenth century, ports in Kathiawar and Kutch in Gujarat rose in prominence (Das Gupta 1987).

${ }^{21}$ It was during this time that he adopted the surname Mehta. It seems that his relatives always called for him when they needed him as 'Mehta, Mehta, Mehta!', meaning one who keeps accounts. His original surname was Badiani (interview with D. N. Mehta, Bombay, 20 May 1996).
} 
Expressed (Mehta 1987) provides an opportunity to consider Mehta's 'commercial narrative' (Desai 2011) not as complete, objective or hagiographic, but rather as a constructed and interpreted roadmap to follow the way in which Mehta and his progeny constructed a migration history, one to be remembered not only during the 1970 s tumult of expulsion but also during the anti-company Mabira forest protests of the 1990s.

Mehta wrote that he viewed Africa 'not as a safari for tourists, but a land of commercial enterprise and youthful adventure' (Mehta 1987: 74), ${ }^{22}$ and his particular depiction of Africa reflected a sort of denial or deliberate opposition to what may have been common assumptions about why Indians ventured to Africa during the early years of the twentieth century. His autobiographical recollections are also revealing as part of the collective migratory memory not only of his family - his wife and two sons in particular (whom I met) - but also of a collective Uganda Indian community. In Mehta's case, he was recalling the desires of his youthful 'adventuresome' self from the 1960s. In his first decade in East Africa, Mehta established credit with area merchants and eventually was able to open his own shops. With earnings from these small dukas (shops), Mehta acquired the capital needed to establish credit to experiment with larger industries. He entered the cotton trade, first by obtaining cotton seeds and other raw materials from family in India. ${ }^{23} \mathrm{He}$ continued to invest his earnings from selling imported goods from Bombay into new business ventures in East Africa, and later in India (Mehta 1987: 118).

Dhirendra Mehta, N. K. Mehta's son, recalled being told about the concerns of his grandparents when young N. K. Mehta left for East Africa. Mehta's family had been worried about 'sending him off to far-off places, remote places, where there is nobody there, a confined and solitary life'. ${ }^{24}$ However, far from being isolated and dislocated, Mehta found a growing network of Gujarati Indians whose bonds were memories of 'home', trust in one's own community, and a desire for commercial success. Even though East Africa remained a place that was not home for Mehta, at least initially, it would be increasingly filled with a community of Uganda Indians who would not only have an impact on Uganda but would also transform India. Such transformations relied not only on remittances but also on constructing and memorializing Africa in India. ${ }^{25}$ By doing this, Uganda Indians created translocal identities that would shift only slightly as the century unfolded and as expulsion and repatriation entered the narrative.

The economic boom that followed World War One was lucrative for Mehta. He invested his capital in cotton-ginning factories and wrote to prominent Indian firms about developing Africa. Notable industrialists brought Indian capital to East Africa and founded ginneries on a partnership basis in the early 1920s. ${ }^{26}$

\footnotetext{
${ }^{22}$ The 'safari' reference had more salience at the time when he wrote his autobiography during the early to mid-1960s, when safari tourism was more common than it had been half a century earlier.

${ }^{23}$ The Uganda Company was established in approximately 1905.

${ }^{24}$ Interview with D. N. Mehta, Bombay, 18 March 1996.

${ }^{25}$ Industrialists such as the Mehtas used profits made in East Africa to develop Indian infrastructure; he also funded local Ugandan causes.

${ }^{26}$ Homi Mehta, Purshotamdas Thakurdas and Ambalal Sarabai were leading cotton industrialists based in India, all of whom were involved in various capacities with the Indian nationalist movement.
} 
Eventually, Mehta's enterprises grew to include cotton mills and sugar and tea estates. He became one of the most prominent, successful and well-known industrialists not only in East Africa but on both shores of the Indian Ocean. Nanji Kalidas Mehta's commercial legacy continues today through his children and grandchildren, who maintain multiple global bases in London, Dubai, Jinja/ Kampala, Mombasa, Mumbai and Porbandar and serve as executive officers of the Mehta Group of industries. N. K. Mehta's autobiography and the recollections of Dhirendra, Medha and Mahendra Mehta (the elder son and daughterin-law and younger son) offer a methodological means of seeing oral historical sources as part of the memory-making of migration.

The Mehta commercial legacy is tied inextricably to N. K. Mehta's public legacy as memorialized on both sides of the Indian Ocean and in his autobiography. As inheritors of mobile and fluid transnational identities and global economics that began centuries ago, his descendants have actively and successfully sought to cement Mehta's name in Kampala and Jinja (his Ugandan homes) as well as in Porbandar (his Indian home). As inheritors, they have memorialized their founding father on their corporate website, ${ }^{27}$ in the halls of their buildings around the world, in the institutions that he established and that they now manage and expand, and in the regional and national imagination of the state of Gujarat in the Republic of India. Porbandar city itself is a testament to the public memorialization of the Mehta family by the Mehta family, through the schools, gardens and memorials he founded and to which I now turn. These sites not only establish Mehta's legacy, but - and more importantly - they reveal how his migration experience is constructed and remembered.

The ways in which Mehta constructed his identity are articulated in his autobiographical account focused on East Africa, and this 'memory-speaking' reveals the primacy of India. What matters is not only the fact that he constructs and remembers, but how autobiography serves as an essential contribution to migration, memory and community-making. He might have followed his 'destiny' to establish his commercial ventures, even if he did this by transgressing by crossing the kala pani $^{28}$ (Mehta 1987: 105), but he was also systematically involved in India by building schools, libraries, parks and other social and educational structures. Among these was the Arya Kanya Gurukul in Porbandar. Mehta established this residential school for girls based on the model of the Arya Samaj School in Baroda, where his eldest daughter, Savitaben, had studied. The 1937 Gurukul was based on Mehta's idea of giving poor girls a chance of education because 'women's education is economically sound', ${ }^{29}$ with its teachings based on Vaishnav principles. ${ }^{30}$ Daily activities include bathing, puja (worship) and group

\footnotetext{
${ }^{27}$ See <http://www.mehtagroup.com/founder_profile.html\#>, accessed 11 May 2015.

${ }^{28}$ This notion of kala pani (black waters) related to culturally eschewed overseas travel to 'impure' lands. Dhirendra remembered that his father's return from Africa had to be marked by purification rituals upon return to his 'rightful' home: Gujarat, India. However, he speculated that, in his father's case, kala pani referred more to travel to Bombay from rural Gujarat than to travel overseas.

${ }^{29}$ Interview with Mr Joshi, principal of Arya Kanya Gurukul, Porbandar, Gujarat, 21 August 1996.

${ }^{30}$ Vaishnav indicates a form of contemporary Hinduism in which followers display devotion to the deity, Vishnu, and the many incarnations of Vishnu, most prominently Ram and Krishna.
} 
exercise before breakfast, and then studies, play, puja and dinner. Mehta's focus on a Hindu education for girls aligned with late Indian nationalist notions of women's reform for the good of the nation. The Indian nation became key for Mehta in part because he was increasingly connected to nationalist activities, and to Gandhi's vision in particular, but notably from across the sea on another shore. ${ }^{31}$

The other significant site is Bharat Mandir; this does not have any direct curricular purpose but serves a powerful and symbolic role in the education of girls (and, more recently, for global tourists) and in the creation of a collective memory of the larger community. ${ }^{32}$ This 'temple' to India is not a place of religious ritual and prayer, but signifies a devotion to country and family. The country is India, but, by default, it is also Uganda; the family is the Mehtas but also the people of Porbandar, his city 'family'. The Mehtas reinforced Indian heritage and pride despite the 'loss' of the family to Uganda. ${ }^{33}$ The structure is a beacon for memory: of Nanji Kalidas Mehta himself, of the global Mehta family, of India, and of Porbandar. One 2012 visitor from Mumbai gave a four-star rating to Bharat Mandir on a travel website and commented that it was a 'great effort by the industrialist/philanthropist who set this up'. They continued by lamenting that Indian students in high-ranking international schools were learning about the American Revolution and Great Britain, but not about 'thousands of years of Indian history and culture'. ${ }^{34}$ This reviewer, like Mehta, wanted the Indian nation to be glorified; the monumental structure of Bharat Mandir fulfils architecturally the memory of a nascent nation and is an intentional creation of historical memory.

Like many buildings on the Gurukul's campus, Bharat Mandir is an impressive whitewashed building. Atop the central balcony is a large engraved $\mathrm{Om}$. Inside sits a room-sized relief map of India, made of white marble and surrounded by twenty-four four-sided columns which feature a total of ninety-six relief sculptures of historical and mythological figures who, according to Mehta, 'have contributed to the building up of Indian culture' (Mehta 1987: 209). Built with the aim of education and national integration, Bharat Mandir is a monument to N. K. Mehta's Indian nationalist imagination and his acceptance of Hindu reformist Arya Samaj ${ }^{35}$ teachings. Notably, it was in East Africa that Mehta learned about Hindu reformist ideas ${ }^{36}$ and became interested in the notion of a new Hindu identity espoused by the founder of Arya Samaj. For Mehta, a new Hindu identity

\footnotetext{
${ }^{31}$ Interview with D. N. Mehta, Bombay, 20 May 1996.

${ }^{32}$ Bharat Mandir means 'temple of India'.

${ }^{33}$ Agnew (2005) describes a parallel 'loss' of material culture that has the capacity to create renewed ties of history and heritage.

${ }^{34}$ See Bharat Mandir review, posted on Tripadvisor.com, 13 April $2013<$ http://www.tripadvisor. com/Attraction_Review-g635748-d2008433-Reviews-Bharat_Mandir-Porbandar_Gujarat. html>, accessed 14 May 2015.

${ }^{35}$ The Arya Samaj was a late nineteenth-century Hindu reform movement founded by Gujarat native Dayananda Saraswati. Part of its mission was to establish Vedic (that is, particular forms of what is now called Hindu) schools or gurukuls around India. The Arya Samaj eventually held more influence in the north-western state of Punjab, India, than in Gujarat. Nevertheless, in Porbandar, the Gurukul's teaching of girls continues today.

${ }^{36}$ Mehta was first influenced by the Arya Samaj teachings when the Arya Kanya Gurukul in Baroda sent a fundraising mission to East Africa in 1926 (interview with D. N. Mehta, Porbandar, Gujarat, 22 August 1996).
} 
was, in part, a new Indian identity, something that perhaps was necessary in what may have seemed like a marginal overseas location. It was clearly important to Mehta's own memory of place and home, and to his identity. His autobiographical recollections offer us a window into his anxiety about Hindu practices and the nation in the making. The way in which India figured in N. K. Mehta's imagination is exemplified by the Arya Kanya Gurukul and Bharat Mandir. East African Indian migrants' interest in Indian nationalism - and, in this case, in Hindu practices on Indian soil - enabled families such as the Mehtas to influence the public memory of those who had left. While based in Uganda, the Mehta family's institutional presence in Porbandar has memorialized them forever in the city's daily life and landscape. Mehta provided resources in order to spread the brand of nationalism in which he believed. Mehta's life history, as recalled in his account as well as through his sons' and daughter-in-law's accounts, is important for understanding his multi-local position, a construction of identity with a transnational perspective, and his own memory - or desired memory - of India. With his capital investment, he was able to influence what India could be, and therefore what Uganda Indians could inherit. In this there is remembrance of one nation (India), a gesture towards another (Uganda), and a culmination in which Nanji Kalidas, the patriarch, and his globally scattered descendants create a 'transnational circularity of memory' (Erll 2011). Nation and family are constructed and reconstructed in the collective memory (ibid:: 306) of Porbandar.

The founding and maintenance of a girls' school and the construction of the 'temple to India' (Bharat Mandir) exemplify Mehta's construction of identity, especially notions of belonging to India. Far more impactful, however, is the memorializing of Porbandar via its most esteemed son of the soil, M. K. Gandhi. Mehta's Porbandar tribute to Gandhi is his family's crowning glory, for the Mehtas serve as commercial maharajas ${ }^{37}$ not only of Uganda but of Gujarat. The purchase of the Porbandar building in which Gandhi was born confirmed to the world an irrevocable alignment of N. K. Mehta with M. K. Gandhi. Mehta had the structure renovated into a grand memorial and museum, now called Kirti Mandir. ${ }^{38}$ Most maps of present-day India mark Porbandar as a 'place of tourist importance' solely due to the existence of this recently created landmark. While in East Africa, Mehta had read about Gandhi's struggle for rights in South Africa and for independence in India, and eventually he made contributions to fund Gandhi's activities. He first came into contact with Gandhi in 1915 during a visit to India ${ }^{39}$ and later served as a delegate for Indians in East Africa. On the building walls throughout the Gurukul, in the pages of the Gurukul's pamphlets and in Mehta's autobiography are photographs of and quotes from leading politicians from India, East Africa and England. ${ }^{40}$ For Mehta, there was a fluid relationship between what he believed was good for

\footnotetext{
${ }^{37}$ Maharajas are royalty or great kings.

${ }^{38}$ Kirti Mandir is a memorial temple.

${ }^{39}$ In 1915 , Gandhi would have just returned to India after approximately twenty years in South Africa, working with the South Africa Indian National Congress for rights and better treatment of Indians in South Africa.

${ }^{40}$ Indian examples include Jawaharlal Nehru (Prime Minister, pamphlet published 1955), Indira Gandhi (Prime Minister, 1967), and Zail Singh (Union Home Minister, 1982). All photographs include Mehta and all quotes praise him for his actions and generosity. Mehta hosted other
} 
Porbandar, for India, and for Indians in East Africa, and the way in which Mehta saw these concerns as intertwined is reflected in the various buildings and programmes he established.

Mehta was determined to glorify Gandhi's Porbandar heritage and to promote the spirit of Gandhi's message in Gujarat as well as for Indians in East Africa. ${ }^{41}$ Mehta's loyalties and connections to Gandhi relied primarily on their shared Porbandar roots. ${ }^{42}$ Apparently, Mehta first had the idea to create a shrine in Gandhi's Porbandar birthplace when he hosted Gandhi at his Panchgani residence in 1944. His resolve to do this increased after hearing the South African Education Minister, Mr Hofmeyr, remark, 'Your people [Indians] seem to be in the dark of the value of greatness Gandhi possesses. Had there been another country in your place, it would have built an inspiring memorial near this place and preserved the old house for posterity to visit and derive inspiration therefrom. ${ }^{43}$ After Gandhi rejected several requests, he eventually gave permission to Mehta to buy the building. ${ }^{44}$ Although Mehta donated the building to the Government of India after monumentalizing the original structure and detaching himself from its management, the Mehta family continues to support its upkeep. Kirti Mandir now stands in Porbandar and serves as a historic landmark commemorating Gandhi, as the pride of the city and the sole object of its tourism, and as an indirect tribute to the city's primary benefactor and unofficial Maharaja, Nanji Kalidas Mehta. Memorializing Gandhi in Porbandar has memorialized Mehta as part of the production of narratives about those who leave (Gandhi to South Africa and Mehta to East Africa) being vital to the places they have left. Gone but not forgotten.

Mehta's investment in India was more than simply emotional, nostalgic or philanthropic. He connected people, capital and governments in ways that could not be easily forgotten or reversed. Porbandar figured significantly since the larger city of Ahmedabad was already a well-developed textile centre, a 'Manchester of India' ${ }^{45}$ He built Maharana Mills in Porbandar in the early 1930s, the first textile mill in Saurashtra district, and later established a hydrogen plant and eventually a cement factory on the outskirts of Porbandar, in Ranavav; this continues to be a major technologically sophisticated player in India's cement production and distribution industry. ${ }^{46}$ While Mehta started to make his mark in Uganda in 1901, he most consciously and intentionally had an impact on the public

\footnotetext{
political events, such as the 'Fourth Kathiawar Political Conference for the States', which was held on the grounds of the Mehta's Maharana Mills in Gujarat.

${ }^{41}$ The relationship between Gandhi's activities in South Africa and the support/appropriation of his political philosophies and social mandates by the Gujarati business community of East Africa are crucial to seeing the networks between Gujarat and Southern and East Africa.

${ }^{42}$ Interview with D. N. Mehta, Porbandar, Gujarat, 21 August 1996.

${ }^{43}$ From an unpublished pamphlet entitled 'A golden jubilee presentation: Arya Kanya Gurukul'.

${ }^{44}$ The land on which the house was built was originally given to M. K. Gandhi's grandfather, Rahidas Gandhi, as a title deed from Maharaja Sartanji of Porbandar in approximately $1776 \mathrm{CE}$ (from the title deed at Kirti Mandir, Porbandar). The year is the equivalent of the Vikram Somvath year 1833.

${ }^{45}$ Interview with D. N. Mehta, Bombay, 18 March 1996.

${ }^{46}$ The brand name is Hathi (elephant) Cement.
} 
memorialization of East Africa in the Porbandar imagination through the memory sites that dot the cityscape.

Indians had been 'making place' through their shifting geopolitical and commercial environments and India and East Africa had trade connections for centuries before Europeans navigated the north-western Indian Ocean, yet more recent nineteenth- to twenty-first-century movements of Indians to Uganda provide ways to trace and complicate 'transnationalism' and 'translocalities'. ${ }^{47}$ They have remapped the cultural, religious, economic and regional identities of Gujarat or Punjab on Uganda or Kenya (Nair 2001). ${ }^{48}$ The Mehtas have come to represent the Uganda Indian community, and this led the 2007 protestors against the Mabira forest acquisition to target Indians and Indian businesses in general but not the Mehta Group or their Sugar Corporation of Uganda directly. Greatly complicating the xenophobic nature of the protests by non-Indian Ugandans is the fact that Mahendra Mehta (son of Nanji Kalidas) said about his family: 'The Mehtas are more Ugandan than some Ugandans. ${ }^{49}$ Without the Mehta family, one wonders, what is the place of the Uganda Indian community, of Gandhi's Gujarat roots, or of Porbandar's commercial present? It is precisely through their remembering on a large scale that 'home' is recreated, recalled and constructed across the seas. Mahendra Mehta returned to Uganda after Amin was ousted when Provisional President Lule asked him 'to come home' and discuss rebuilding the Ugandan economy. Mehta returned to his house to find that it was occupied by a general in the Tanzanian army. He informed the general that he had been the former occupant and that 'this used to be my home'. The general offered him a pastry and tea. Mehta recalled: 'Within fifteen minutes, 2,000 people had gathered, singings songs to welcome me home. I had tears in my eyes. They wanted to touch me. ${ }^{50}$ Without such public proclamations and memory-making moments, home and diaspora both vanish; settlement and return do not take place without memories and affirmations (Reeves and Rai 2006: 18). The later refugee/repatriate status of Uganda Indians presents a historically unusual moment and exemplifies multiple themes of transnationality: ${ }^{51}$ movement of capital; a consciousness and memory of trauma and desire - that is, 'belonging and longing'; and an alignment of localities. Uganda profits invested in India developed Mehta's Porbandar; he aligned Gujarat with Uganda. For the 2011 dual commemoration of Mehta's 175th anniversary and the platinum jubilee of the Arya Kanya school, the Mehta Group's website proclaimed: '26th and 27th November 2011 are two days that will be etched in the memory of the citizens of the historic city of Porbandar, Gujarat for years to come. ${ }^{52}$ The memory sites Mehta created provide a collective memory; he is remembered and thus his legacy is cemented.

\footnotetext{
${ }^{47}$ Steven Vertovec outlines various approaches to the study of 'transnationalism' (1999). In the article, he suggests that one of the many ways in which 'transnationalism' is deployed is through reconsiderations and constructions of 'place' and 'locality'. In it, he cites Arjun Appadurai (1995), Luin Goldring (1998) and Robert C. Smith (1998).

${ }^{48}$ For more on the politics of identity among Kenya Indians, see Nair (2008).

${ }^{49}$ Interview with Mahendra Mehta, Lugazi, Uganda, 6 December 2005.

${ }^{50}$ Ibid.

${ }^{51}$ For further discussion of transnationality, see Vertovec (1999), Appadurai (1995) and Rai and Reeves (2009).

${ }^{52}$ See <http://www.mehtagroup.com/dual_celebration.html\#>, accessed 14 May 2015.
} 


\section{Two neighbourhoods, one history: how refugees remember ${ }^{53}$}

In August 1972, just after President Amin set the deadline for his initial expulsion order relating to Indians who were not Ugandan citizens, India's Foreign Minister M. A. Rahman was sent as official envoy from New Delhi to Kampala to discuss the issue of British passport-holding Indians being ordered to leave Uganda. The New York Times described this decision for Rahman to go to Kampala as a reaction to worldwide agitation at the expulsion order, especially in the US and Britain, since until then the 'Indian Government [had] been largely indifferent to the plight of the Asians in Uganda'. ${ }^{54}$ Most Uganda Indians in 1972 were British passport holders (Weinraub 1972). In other words, prior to the announcement of Rahman's trip, the Indian government had been largely silent on the issue of President Amin's expulsion order of all Indians from Uganda. Journalists and many scholars have represented the Government of India's position as one that viewed the problem as a British one ${ }^{55}$ rather than Indian or Ugandan. Those who eventually returned to India describe narratives of expulsion and resettlement based on a fictive memory of passport-based status.

While there is some evidence that the Government of India was ready to take in Uganda Indians who relinquished their British passports and took Indian citizenship, it appears that this offer was not compelling enough to entice large numbers of refugees (Gupta 1975: 137-8). Expelled Indians were also turned away from London, partly due to Britain's 1968 Immigration Act, which was based on a principle of 'patriality' that restricted immigration to the United Kingdom based on birth and parental birth and naturalization. Out of the over 50,000 British passport-holding refugees, a few thousand at a time were granted entry into the UK by the Foreign Secretary despite disagreements in parliament (Cerutti 1972). Approximately 30,000 were given refuge in Britain early on (Roy 2012), and, by 1981, there were over 155,000 South Asians of East African origin in Britain (Peach et al. 1988 cited in Clarke et al. 1990: 167). By 1987, the Uganda Indians were a sizeable subset of the over 1.2 million South Asians, of varied origins, living in the United Kingdom (Clarke et al. 1990: 2). For most Uganda Indian refugees in 1972, however, Britain was not an option. A 1972 New York Times headline read: “'Asians go home!” But where is home?' (Short 1972). Not only the nature of migration but also the nature of expulsion and category of citizenship impact the memory of 'home'. Two neighbourhoods in Ahmedabad, unexplored by historians of India and of the Uganda expulsion, offer an opportunity to investigate how the rejected remember. The housing complexes are named 'Uganda Society' and 'Uganda Park'. ${ }^{56}$

\footnotetext{
${ }^{53}$ Pseudonyms have been used in this section for reasons of anonymity.

54، India sending envoy to Uganda for a talk on Asians', New York Times, 25 August 1972 $<$ https://www.nytimes.com/1972/08/25/archives/india-sending-envoy-to-uganda-for-a-talk-onasians.html>. Nonetheless, in this case, only a small percentage (the New York Times estimate is 3,000 ) of the refugees held Indian citizenship. Over 55,000 Indians in Uganda were British passport holders at this time (Weinraub 1972).

${ }^{55}$ Given earlier problems in Kenya, Burma and Sri Lanka, the Indian government has been accustomed to Indian settlers being forced to return to India.

${ }^{56}$ These Ahmedabad neighbourhoods have not previously been explored or their residents' life histories narrated.
} 
Located in Memnagar, not far from Gujarat University and the renowned Indian Institute of Management, is a cooperative housing society comprising approximately eighty-six independent bungalows ${ }^{57}$ named the 'Uganda Society'. In 1974, Rameshbhai Khamar ${ }^{58}$ and other Ugandan refugees carrying British passports, who had not received any initial assistance from the Indian government to resettle in India, made a successful plea to purchase land and develop a housing society for refugees. Their plan specified that society members would be British passport-holding Uganda Indian refugees, and the reason they gave for returning to India rather than going to Britain was that 'India is home'. ${ }^{59}$ Despite such declarations, Khamar recalled his status as a British passport holder with pride. Despite a memory of privilege, he was among the first ordered to leave precisely because of British passport categorization. Thus, he remembered his marker of status as simultaneously empowering and disempowering. 'A Ugandan apartheid' was how he recalled the place he was forced to leave. In Memnagar, he could resurrect that lost, yet never quite existing, position of privilege.

Using personal and business networks in Ahmedabad established over the years of conducting overseas business, this entrepreneurial group secured assistance from the Gujarat Chief Minister. With the Chief Minister taking the lead, the Indian government sanctioned the purchase of private land for the development of a society made up of refugees. The private land originally belonged to Jayantbhai Pasaiwalla (Pasaiwalla meaning the one with money) and was purchased by the Government of India for the Uganda Society. Successful advertising of the available plots in Gujarati newspapers resulted in all of them being sold. ${ }^{60}$

Members of the Uganda Society distinguish their Uganda Society, established for refugees with British passports, from Maninagar's 'Uganda Park', which was for Indian passport holders. Here, the ostensible difference is citizenship, but the invisible features are status and memories of privilege in Uganda. The Khamars, who helped start the Uganda Society, described those who maintained their Indian citizenship as being from working-class, lower-skilled professional and service fields in Uganda. Thus, as the Khamars contended, when these Indian citizens returned to India, they had to secure loans from the Government of India to develop the Uganda Park housing society. Memnagar's Uganda Society members recollected their own neighbourhood's origins as a

\footnotetext{
${ }^{57}$ Out of the eighty-six buildings, only ten were still owned by the original inhabitants or their descendants. Others had been sold to those who did not have any relationship with Uganda. A few plots are big enough for two bungalows. The monthly maintenance fees were 1,000 rupees (Rs.) in 1974. The Executive Council, including a president, secretary and treasurer, administer this historically unique cooperative housing scheme.

${ }^{58}$ In Uganda, Rameshbhai had served as president of the Hindu temple in Jinja. His company owned a maize mill. As a British citizen, Rameshbhai was among the first whom President Amin expelled. Rameshbhai turned over his factory to an employee who was a Uganda Indian with Indian citizenship, thinking that the factory would stay in the hands of an Indian. Once Amin's expulsion orders were revised to include all Indians, regardless of citizenship, the factory was left to a Ugandan army officer. Rameshbhai later learned that his residence and factory were given to Maliyamungu, one of President Amin's many 'right-hand men'.

${ }^{59}$ Interview with Rameshbhai Khamar and Rajitbhai Khamar, Ahmedabad, Gujarat, 19 December 2006.

${ }^{60} \mathrm{Ibid}$. At the time, the plots sold for Rs. 40 per square yard. In 2006, conservative estimates valued the land at Rs. 17,000 per square yard.
} 
collective development scheme, whereas they represented Maninagar's Uganda Park as a government assistance programme for refugees. ${ }^{61}$ The way in which British passport holders remembered their own re-establishment in India vis-à-vis that of Indian passport holders contains a multiplicity of meanings. Importantly, these terms align with the Indian passport holders' perceptions of the two neighbourhoods. Such declarations reinforce conflicting memories of resettlement and status, while such tensions serve to distance the two communities despite a shared historical experience and trauma of displacement and a shared longing for Uganda. Thus, these memories of refugee resettlement in India create identities of difference among groups with shared experiences that are not constructive for either group. The historical memory of these housing societies has come to be characterized and defined based on passport differentiation and thus obscures complex and nuanced narratives of expulsion.

On the other side of the famed Sabarmati River, in the area of Maninagar, sits Uganda Park. The neighbourhood is officially called Dhariyapar Gurjari Vasahut (effectively 'refugee residence') Cooperative Housing Society Ltd. With the help of Vikaschandra Shah, a member of the Labour Ministry of Gujarat, the Uganda Indian refugees were able to secure a loan from the Government of India to purchase 31,000 square yards and to subdivide the area into ninety-six units. ${ }^{62}$ Unlike the Uganda Society, the bungalows in Uganda Park are more modest and in closer proximity to each other. In 1974, the main stakeholders accompanied Shah to Delhi to meet with the secretary in charge of the Maninagar Uganda Park resettlement scheme (for Indian citizens) in order to finalize the release of the land. Nilaybhai Desai described one conversation with the secretary: when looking at the paperwork and plans for the housing scheme, the secretary had asked why it was necessary to have such large houses on the plots. The secretary suggested that these were refugees, after all, and thus needed only one room and one kitchen. Shah explained that these were not ordinary refugees. As even the conventional history of Indians in Uganda reveals, these refugees had been gainfully employed and living comfortably in Uganda before expulsion propelled them back to India as refugees with Indian passports. After the paperwork began in 1974, the Uganda Park organizers were able to secure the land and to lay the foundations in 1975, and the housing cooperative scheme was completed in $1979 .{ }^{63}$ Desai regretted the raised

\footnotetext{
${ }^{61}$ Interview with Rameshbhai Khamar and Rajitbhai Khamar, Ahmedabad, Gujarat, 19 December 2006.

${ }^{62}$ Group interview with D. R. Patel, N. Desai and C. Gajjar, Ahmedabad, Gujarat, 20 December 2006; interview with D. Patel, Ahmedabad, Gujarat, 22 December 2006.

${ }^{63}$ The Government of India gave Rs. 5,000 per house and Rs. 6,000 for resettlement to Maninagar, but only Rs. 3,000 for resettlement into a rural area. The order from the collector of Ahmedabad, as per the Government of India, also indicates that in addition to the loan of Rs. 4,100 for the purchase of housing under the Uganda Repatriate Loan programme, Dineshbhai Patel was eligible for Rs. 1,900 as construction had not started. Furthermore, the government sold the land for Rs. 27 per square yard to purchase Uganda Park, when, in 1973, neighbouring land cost Rs. 125 per square yard. While the plots of Memnagar were purchased for Rs. 40 per square yard, Maninagar's plots were purchased through government subsidies for Rs. 27 per square yard (interview with N. Desai, Ahmedabad, Gujarat, 20 December 2006). This is verified by correspondence from A. Prasad, Collector of Ahmedabad, to Mr Dineshbhai Patel, 1976 (month and day unknown); no. HB/Uganda/Repatriate/REH/Loan document 29-1-1975;
} 
consciousness of their multiple alienations: 'Indian' not Ugandan, 'Indian' without British passports, 'refugee' but not ordinary refugees. Home but not belonging.

During interviews in 2006, Nilaybhai Desai reiterated with insistence that both housing societies were on Government of India land. Desai called India his 'native place' and said: 'I decided to come to India because I didn't want to be stateless.' He explained to me that, despite what I might have learned from my interviews with Uganda Society residents (those former British passport holders), it was important to remember that 'expulsion is expulsion'. 'If you don't come out and face it, then what to do. One must face it,' he lamented. ${ }^{64} \mathrm{He}$ continued that, although the Uganda Society thought of itself differently (as elite in terms of citizenship and class status) because its members were British passport holders at the time, he was aware that Vikaschandra Shah had also supported the efforts of Memnagar's Uganda Society. Desai remembers that, in the 1970s, the two societies were on far more equal footing in the eyes of the Gujarat and Indian governments than would appear from the memories of Memnagar residents. Therefore, even though 'expulsion is expulsion', home is not home. The government aligned the two neighbourhoods in ways disconnected from Memnagar's imagined difference. Expelled Indians who carried British and Indian passports did not mobilize themselves around any common identifier or shared predicament, but rather independently developed their new 'home away from home': a twice displaced home, from Gujarat to Uganda and back again. Same routes, same roots. However, it is with a robust insistence that both routes and roots are relegated to a community's amnesia. Even with the same 'Uganda' prefix before 'Indian', there exists an immense cognitive and conceptual difference in the ways in which Uganda Indians reconfigured themselves back in India, remembered their expulsion and resettlement, and juxtaposed hierarchically their forms of citizenship.

An original member of Memnagar's Uganda Society, Dineshbhai Patel, sold his plot of land and eventually moved to Uganda Park; this was one of the many repercussions of relinquishing his once British and then Ugandan citizenship, and then becoming an Indian citizen. He had fought hard to attain his Ugandan citizenship, and then worked equally hard to attain Indian citizenship. ${ }^{65}$ Over his lifetime, he held the passports of Britain, Uganda and India. His multitransnational life history escapes the historical record. He lives in the fault line of national and archival history writing that does not recognize the deep interconnections between India, Africa and Britain. Not documented in any one colonial archive - whether in London, Entebbe or Gandhinagar - Patel's story, like so many others, has been parcelled out and recorded primarily in memories, in narratives, and in multiple obscure institutional sites. For Patel and the two neighbourhoods, 'refugee', 'Indian' and 'Ugandan' are mutually constituted;

Government of Gujarat, Revenue Department, no. JRB 1075/66012/R, document 3-7-1975; Government of India's Ministry of Supply and Rehabilitations no. 21(4)/75/RH I document, 23-5-1975.

${ }^{64}$ Interview with N. Desai, Ahmedabad, Gujarat, 20 December 2006.

${ }^{65}$ Dineshbhai tried unsuccessfully to attend a nephew's wedding in England and was denied a visa on multiple occasions due to his non-British passport status at the time (interview with D. Patel, Ahmedabad, Gujarat, 22 December 2006). 
furthermore, Patel and the neighbourhoods he has called home also share the institutions that are involved in arranging these settlements. Like Patel, these institutions traverse the seas - the High Commission of India, Kampala; the Government of India's Uganda Compensation Settlement Office (on the Ballard Estate in Mumbai); and the District Magistrate in Ahmedabad. ${ }^{66}$

Differences in identities and memories have been formulated through the histories of migrations, rejections, repatriations and citizenship. Memnagar and Maninagar, two neighbourhoods established in the early 1970s for distinctively categorized but equally expelled Uganda Indians, serve as examples of the preinternet, pre-social media ways in which 'diasporas produce multiple consciousness, histories, and identities that generate difference and challenge homogeneity' (Agnew 2005: 14). The residents of Memnagar and Maninagar had experienced unimaginable displacement, expelled en masse from the only physical home they knew in Uganda to their imagined home in Gujarat. The ability to define and redefine 'home' when community memory and community identity are deterritorialized can be simultaneously liberating and oppressive. Ahmedabad had to be cultivated as a new home since Uganda figured only as a site of memory. Part of the production of home necessitates a revisioning, and perhaps selective misrememberings.

Despite different 'home' experiences, for those who were expelled in 1972, a return to Uganda in the 1990s was desirable and welcomed. This final category of migrant identity that I explore, those Indians who accepted the Government of Uganda's invitation to return under the Repatriation and Resettlement Scheme in the 1990s, offers a final piece of evidence for the need for scholars to continue to see diaspora identities, migration memories and notions of home as nuanced, multivocal and shifting.

\section{Kampala: one 'community', two histories ${ }^{67}$}

Between 1991 and 1996, the first five years after the Ugandan government's repatriation schemes were announced, close to 2,000 properties in Uganda were repossessed and returned to their original Indian owners (Obwona n.d.). The number of those who have gone back to Uganda is estimated at approximately 15,000 (Selva 2005 ) - out of approximately 90,000 who were expelled initially. For some claimants, it has been a cumbersome bureaucratic process of presenting deeds and titles. For most, however, it was far more arduous: locating their own original paperwork or their family's was a challenge given the circumstances under which they left Uganda in 1972. Other families have been battling in the courts with the Ugandans who took over their homes or the businessmen who set up in their shops. Uganda scholars have noted that, for the Ugandans who moved into abandoned Indian residences and established businesses in abandoned

\footnotetext{
${ }^{66}$ From local to central to overseas, multiple institutional entities are in dialogue to deal with assets in Uganda, loan amounts in Ahmedabad, and insurance settlements. Out of the estimated 6,000 Ugandan Indian refugees who came to India, over 200 were housed in these two Ahmedabad societies.

${ }^{67}$ Pseudonyms have been used in this section for reasons of anonymity.
} 
Indian-owned stores, there was absolutely no incentive or sense of historical corrective to return the properties. ${ }^{68}$ Given the many decades that have passed, an entire generation of Ugandans have grown up without the memory of expulsion. Such amnesia exists not only for contemporary Ugandans, but also for some descendants of returning Indians, especially those who were not themselves expelled. Ugandans pose the question: why should they now be 'expelled' from their homes and businesses? The Ugandan government has had to navigate the tricky and contested ground between their Ugandan constituency and their invited Indian repatriates without heightening discord. Legal battles rage on as disagreements over history and identity and historical memory have emerged. While Indian returnees to Uganda can be defined in temporal terms as 'postcolonial' migrants, I suggest that their histories and experiences are connected to earlier colonial migrations. How both sets of migrants conceive of and remember their own histories differs in substantive ways from their contemporary counterparts: a quite different group of migrants who have been coming to Uganda directly from India over the last several years.

The production of written material crystallized and collectivized a reformulated Uganda Indian community in the public sphere; newly built community structures helped evoke the memory of an earlier community. They built upon the existing community buildings, further adding to the memory sites speckling Kampala. Kampala Indians seem to be declaring: 'We were here, we left, and we're back. See us all around the city.' However, the audience is only in part the local Ugandan community; this is mainly a proclamation to themselves to re-establish Uganda in the community's historical memory.

Contemporary Kampala (as well as elsewhere in Uganda) has witnessed the return of thousands of Indians. There have been predictable and unpredictable tensions that have arisen in the 1990s and 2000s. Of those who returned, most were propertied citizens and some were middle-class returnees who came back to claim properties only to sell them and leave again to their post-expulsion new-found homes. These middle-class returnees had found economic success and political stability elsewhere (primarily in North America and the UK, but also in continental Europe) and did not have any intention of resettling in Kampala. Another generation of returnees came under their parents' cloaks in order to take advantage of small opportunities that may be afforded them by the Government of Uganda. ${ }^{69}$ An entire sociocultural world has been revived and has re-emerged as a result of the reclaimed properties and the presence of a returned community. One of those who returned to reclaim property, Pankaj Patel,${ }^{70}$ recalled how he expected to find no remnants of his former life. He described his discoveries as bittersweet and revealing:

One thing people say is that many things are lost. One thing that is very interesting is that if you go to the department and ask about your car licence or driver's permit ...

\footnotetext{
${ }^{68}$ Personal communication with G. Asiimwe, H. Hanson and S. Rutabukuka, Kampala, Uganda, 2 December 2005.

${ }^{69}$ Ibid.

${ }^{70}$ Patel's great-uncle was recruited to East Africa by the British in 1910 to work in the postal service.
} 
everything is there. If I just go and say, I had a licence back in $1950 \ldots$ this is fifty years old, but I will get a record ... I went to the company to find a record about my father and how he started a business in 1915-20 but you know those records have been kept. The most destroyed was when we came here [Kampala] to stay. We were looted twice in our house. Everything was taken away from us. Maybe it's wrong to always complain about the old photographs, the family pictures, you know? And even our gods. ${ }^{71}$ They took them away and then they came back to our place and said, 'Do you want to buy this one?' The things that they took away and then tried to sell back to us. Everything, not even a single spoon, was left in our home in 1985. Those are the things that are in our prayers ... in our prayers, we forgive them. ${ }^{72}$

The traces of Patel's family's life in Kampala had been reduced to bureaucratic artefacts such as driver's licences and business records, but the sentimental snapshots were gone forever and sacred objects were ransomed back to their original owners. Patel prayed, forgave, and remade a home in Kampala. He also helped resurrect community organizations for the Indians, both for returnees like his family and for newcomers. In his particular case, he became the chairman of the India Association and a trustee of other Indian community organizations. Kampala's landscape transformed to reflect the burgeoning Indian community.

In the heart of downtown Kampala, within a few blocks of each other, are several Indian religious centres: a Swaminarayan temple (founded in 1996), a Sikh gurdwara, and, immediately next door (actually sharing a dividing wall), the Sanatan Dharma Hindu temple. In other parts of the city are the Ismaili Jamaat Khana (1930s) and the Goan-run Christ the King Catholic church. ${ }^{73}$ Of these various religious centres, some, like the Swaminarayan temple, were established in the post-1990s migration era. Others, such as Christ the King church and the Jamaat Khana, are part of the early twentieth-century diverse religious community of Uganda Indians. The Patidar Samaj ${ }^{74}$ is an active site for community events and, judging by visible building renovations and the purchase of nearby properties to expand the Samaj's compound, it appears to be a very well-funded association. The India Association of Uganda has also reclaimed its vibrancy after a long hiatus, with an active membership list of over 1,000. The return of these properties was also part of the Uganda Custodian Board's repossession plan: an estimated 500 community institutions have been returned. The religious and social organizations are primarily comprised of two types of members: Indian returnees and their descendants; and 'newcomers' who have arrived in the last several years from India.

Each of the community associations has worked actively to welcome 'newcomers', and the annual commemorative booklets spend several pages reviewing the history of the Indian community in East Africa generally and Kampala specifically. Any mention of the expulsion is often a first-hand account, but tends to leave the reader with a sense of hope rather than despair. Here, there is a

\footnotetext{
${ }^{71}$ Patel is referring to murtis, small carved statues of Hindu gods and goddesses, used for homebased worship.

${ }^{72}$ Interview with P. Patel, Kampala, Uganda, 29 November 2005.

${ }^{73}$ Founded in 1930, as noted in the publication 1930-2005 Christ the King Commemorative.

${ }^{74}$ Patidar refers to a sub-caste community, most commonly associated with those with the last name Patel, who come from the Charotar district of Gujarat, India.
} 
need to recall and retell a story that is still present for some but is invisible for those who did not live through it. This requires a certain tactful balance in sharing the memory of expulsion with those who do not know or care about it. The India Association's written material unfailingly includes reprints of speeches by India's elected leaders as a manifesto of connection to one 'homeland'. In fact, on the office wall behind the director's desk were large framed portraits of Ugandan President Museveni, then Indian President Abdul Kalam, and, of course, Mahatma Gandhi. Like their late nineteenth- and early twentiethcentury predecessors such as N. K. Mehta, the new migrants from India sought economic opportunity. Like their late nineteenth- and early twentieth-century predecessors, the new migrants arrived to find a homeland that was an extension of the one they left. Indeed, rather than leaving behind 'home', over a century of migrants have brought home with them and have extended it back across the seas. Modes of dress and linguistic, religious and culinary traditions, as well as so many other sociocultural features, were reproducible and reproduced within urban Uganda. ${ }^{75} \mathrm{New}$ Indian migrants were skilled primarily in fields such as healthcare, teaching, and software and hardware engineering. A secondary population of Indians came from petty trader backgrounds and sought success in the Kampala marketplace. Interestingly, these new merchants from India re-inhabited the exact space that was the 'Indian bazaar' in old Kampala. Alleyway after alleyway reminded customers of marketplaces in Mumbai, Manhattan's Lower East Side or Chinatown, but, more importantly, of old Kampala. The way in which the streetscape itself elicits the past serves as a memory site demarcating a return of the 'Indian bazaar' and the Indian community. Kampala's 'Electronics Way' resembles any of these older and global colonial-era urban marketplaces; it is filled with new migrants from India selling made-in-China electronic gadgets. Bargaining and bustling filled the air. There was a familiarity in the sensory experiences of the marketplace; however, the line was clear for newcomers: Kampala is not Ahmedabad, not Mumbai. Reinserting Indian merchants into the once Indian shops held meaning and nostalgia for the expelled generation alone. For newcomers, shops were easily accessible and cost-effective retail spaces in this unfamiliar venue that was purely business.

Despite the efforts of the returned generations to inculcate a sense of shared purpose and community in Kampala, new migrants do not identify with being a 'Uganda Indian' and do not harbour any commitment to their place of temporary residence. For these new Indian migrants, it is not Kampala that is home but rather the recreated Indian homeland within Kampala. The places of worship and spaces of social life have been the sites where the homeland exists. This stands in stark juxtaposition to the generation who returned to Kampala because Kampala (not Toronto, not Leicester, not Porbandar) was home. For new migrants - those arriving independently in the $1990 \mathrm{~s}$ - the investment in leasing retail space has not been about foreign direct investment into Uganda, but rather about remittances to Gujarat and other parts of India. The tensions between the returned and the new generations of Indians have not been palpable at public functions or in the marketplaces, but they have been clear in other ways. For instance, the returned

\footnotetext{
${ }^{75}$ It is important to note, however, that early migrants learned Swahili and participated in historically particular ways and for strategic purposes in an East African cultural world.
} 
generations of Indians have invested in more solid and fixed assets, thus providing a display of confidence and security to the Ugandan government and Ugandan business associates. The newer migrants, even the few who are in the financial position of being able to invest, have channelled funds into sectors that one can easily liquidate in times of political crisis or non-profitability. ${ }^{76}$ The varying tactics of these different groups of Uganda Indians have been emblematic of the 'dialectics of belonging and longing' (van der Veer 1995: 4); they divide into those who have chosen to entrench themselves deeply in the Ugandan economy ${ }^{77}$ and those who have stayed closer to the surface, ${ }^{78}$ ready to make a quick escape if necessary. Recall Rameshbhai and the Khamar family who set up Memnagar's Uganda Society for British passport-holding citizens. Like those in other industries, upon their return to Uganda, the Khamars attempted to reclaim their maize mill in Jinja. After trying to run a profitable business in Jinja from 1992 to 1997, they eventually returned to India, finding that the Ugandan diet had changed drastically since their first venture. Since the 1970s, the influx of other grains from elsewhere in Uganda and other parts of Africa had resulted in a maize mill no longer being a lucrative business venture. Although Rameshbhai returned to stay in India yet again (first with expulsion and then following a failed 1990s business), he remembered his decision being definitive because India was home - although he made no apology for his 1990s return to Uganda. Rameshbhai set up his nephew, Amit Patel, with connections to establish a mineral water company in Uganda. ${ }^{79}$ Amit Patel eventually started a sugar factory in addition to the mineral water business. Yet Amit's presence is not saturated with nostalgia or memory-making. In a similar way that 'expulsion is expulsion' ${ }^{80}$ for Amit Patel 'business is business'. ${ }^{81}$

Families like the Khamars moved often and easily, despite challenges, over decades, back and forth between India and Uganda. Their lives, their business, their families, their histories and their memories are tied inextricably to multiple sites across the seas. For returned individuals and families, home was not simply India; home included Uganda, as evidenced in Rameshbhai Khamar's investment in his nephew's business in Uganda, despite his own failed business there. Evidence of his nostalgia for a better time, a sense of fitting in and fulfilment now gone, was shown when he poignantly recalled his days in the maize mill in Jinja: 'My African name was kazi nyingi, one who works too much.' The Khamars in the last decade of the twentieth century did what the Mehtas had done in the first decade of the century: they upend the notion that migrant networks, imaginations and memories are linear, unilateral and fleeting. Rather, lived experiences of migrants move circularly, and carry with them immense and varied memories and narratives that, in the case of Uganda Indians, are a story that continues in Uganda despite an expulsion over four decades ago.

\footnotetext{
${ }^{76}$ Personal communication with G. Asiimwe, Kampala, Uganda, 2 December 2005.

${ }^{77}$ These are the repatriated Indians who received incentives to return and to invest.

${ }^{78}$ These are the new migrants who opened up small shops, for example, without a more entrenched investment in the Ugandan economy.

${ }^{79}$ As a researcher and traveller in Kampala and Jinja, I can attest to the fact that bottled mineral water is a highly desired commodity in Uganda.

${ }^{80}$ Interview with N. Desai, Ahmedabad, Gujarat, 20 December 2006.

${ }^{81}$ Interview with A. Patel, Ahmedabad, Gujarat, 22 December 2006.
} 


\section{Conclusion: revered, reviled, rejected, returned ... and remembered}

These modifiers about Indians in Uganda from the late nineteenth to the late twentieth century provide a narrative template that reflects a simplified and popularized history. Indians arrived, became (too) successful, were kicked out, and then were invited and incentivized to return. However, the final - remembered modifier is not evident in an archival history that neglects the collective memory and memory sites of a community. The records created by British colonial sources, Government of India archives and East African archives reproduce an incomplete history. Such narratives only focus on sites of origin or arrival rather than following migrants and their memories (as researchers must do themselves), hopscotching between places of experience and inquiry. ${ }^{82}$

Communities of Indians, in particular from areas of Gujarat, were part of a social, economic and political network that included Ahmedabad and Kampala, Porbandar and Jinja, Bombay and Nairobi. Colonial-era and postcolonial returnees manage to long and to belong. India was and continues to be a source of raw materials and a market for selling goods, not to mention a site of matrimonial alliances and a time-immemorial home, and imagined home, for refugees. India could remain home even for those who had never been there and those who did not want to be there. Similarly, East Africa easily exists as part of a western Indian framework for marriage, for business and for political activities, despite the memories, tales of memories and nightmares of expulsion.

The emancipatory promise of 'transnationalist' approaches (Smith and Guarnizo 1998) has limitations. A revisioning of the Uganda-Gujarat circularities, however, captures realities of the late twentieth-century north-western Indian Ocean and enables me to clarify an assumed metanarrative. ${ }^{83}$ India and Africa, as overlapping intellectual and living spaces, are ripe for such new methodological interventions. Postcolonial circularities continue, and those who arrive or return manage to long and to belong (van der Veer 1995: 4). Where India figures in Uganda Indians' self-perception and material realities is clear when examining the voluntary associations, the East Africa to India round trips, and the financial investment. Where Uganda figures in the consciousness of founders or descendants of Memnagar and Maninagar repatriate societies has been less clear for reasons similar to those relating to India.

'Translocal' histories and individuals remap places, and re-memorialize the past that migrants, and in some cases multiply-mobile migrants, have lived. If we only understood Devang Rawal in the context of his 2007 protests and subsequent death, the picture would be incomplete. He has not been forgotten by Uganda, and the way he is remembered is directly tied to memories of past expulsion and traumas that continue to haunt the country. Mahendra Mehta said in 2011 that he is no longer interested in the Mabira forests for expanding his sugarcane production (Njoroge 2011). Mehta evoked the public outcry in 2007 and,

\footnotetext{
${ }^{82}$ Exceptions are, for example, Michael Twaddle (1975) and Mahmood Mamdani (1976; 2011).

${ }^{83}$ Much of the scholarship in the aftermath of the 1972 expulsion either appears defensive and apologist - Robert Gregory's The Rise and Fall of Philanthropy (1992) or Ramchandani's India and Africa (1980), for instance - or ignores the role of the Government of India in assisting repatriates in the early 1970s, for example in journalistic accounts from The New York Times and The Washington Post.
} 
according to sources, his 'sudden change of heart' may be attributed to pressure from the Indian community in Uganda, who, in fear of a repeat of the 2007 incidents, pressured the company to withdraw from Mabira (ibid.). Similarly, a group of over 100 Indians provided a statement to the media: 'Uganda Asians for Mabira. Save Mabira! Oppose Greed!' The Mehta family and the Sugar Corporation were given a chance to recall and reinvest their priorities, established over a century of displacement and disruption followed by reconciliation and renewal. On that day, with that declaration, Uganda Indians advanced their goals, as a community, recalling the 2007 protest and the related deaths of innocent Indians (ibid.). An Indian community that lives amidst the ghosts of colonial and postcolonial 'apartheid' Uganda must tread carefully, understanding its complex history and history's inevitable repetitions, and with an honest reckoning about their new negotiated home, a shared and simultaneously familiar yet unfamiliar one.

\section{References}

Agnew, V. (ed.) (2005) Diaspora, Memory, and Identity: a search for home. Toronto: University of Toronto Press.

Allen, C. (1981) 'The Indian Merchant Community in Masqat', Bulletin of the School of Oriental and African Studies 44 (1): 39-53.

Alpers, E. (2013) The Indian Ocean in World History. Oxford: Oxford University Press.

Anderson, C. (2012) Subaltern Lives: biographies of colonialism in the Indian Ocean world, 1790-1920. Cambridge: Cambridge University Press.

Appadurai, A. (1995) 'The production of locality' in R. Fardon (ed.), Counterworks: managing the diversity of knowledge. London: Routledge.

Appadurai, A. (1996) Modernity at Large: cultural dimensions of globalization. Minneapolis MN: University of Minnesota Press.

Benmayor, R. and A. Skotnes (eds) (1994) Migration and Identity: international yearbook of oral history and life stories. Volume 3. Oxford: Oxford University Press.

Bose, S. (2006) A Hundred Horizons: the Indian Ocean in the age of global empire. Cambridge MA: Harvard University Press.

Cerutti, J. (1972) 'Britain hits Uganda on Asian exit', Chicago Tribune, 8 August.

Chaudhuri, K. N. (1985) Trade and Civilisation in the Indian Ocean: an economic history from the rise of Islam to 1750. Cambridge: Cambridge University Press.

Clarke, C., C. Peach and S. Vertovec (eds) (1990) South Asians Overseas: migration and ethnicity. Cambridge and New York NY: Cambridge University Press.

Cohen, R. (ed.) (1995) The Cambridge Survey of World Migration. Cambridge: Cambridge University Press.

Das Gupta, A. (1987) 'India and the Indian Ocean in the eighteenth century' in A. Das Gupta and M. N. Pearson (eds), India and the Indian Ocean, 15001800. Calcutta: Oxford University Press.

Desai, G. (2011) 'Commerce as romance: Nanji Kalidas Mehta's Dream HalfExpressed', Research in African Literature (42) 3: 147-65.

Erll, A. (2011) 'Locating family in cultural memory studies', Journal of Comparative Family Studies 42 (3): 303-18. 
Freitag, U. (2011) 'Inter-oceanic migrations from an Indian Ocean perspective, 1830s-1930s' in D. Gabaccia and D. Hoerder (eds), Connecting Seas and Connected Ocean Rims: Indian, Atlantic, and Pacific Oceans and China Seas migrations. Leiden: Brill.

Goldring, L. (1998) 'The power of status in transnational social fields' in M. P. Smith and L. E. Guarnizo (eds), Transnationalism from Below. New Brunswick NJ: Transaction Publishers.

Gregory, R. G. (1971) India and East Africa: a history of race relations within the British Empire, 1890-1939. Oxford: Clarendon Press.

Gregory, R. G. (1992) The Rise and Fall of Philanthropy in East Africa: the Asian contribution. New Brunswick NJ: Transaction Publishers.

Gregory, R. G. (1993) South Asians in East Africa: an economic and social history, 1890-1980. Boulder CO: Westview Press.

Gupta, A. (1975) 'India and the Asians in East Africa' in M. Twaddle (ed.), Expulsion of a Minority: essays on Uganda Asians. London: Athlone Press.

Lucassen, J. and L. Lucassen (eds) (1997) Migration, Migration History, History: old paradigms and new perspectives. Berne: Peter Lang AG.

Ludden, D. (ed.) (2002) Reading Subaltern Studies: critical history, contested meaning, and the globalization of South Asia. London: Anthem Press.

Ludden, D. (2003) 'Maps in the mind and the mobility of Asia', Journal of Asian Studies 62 (4): 1057-78.

Machado, P. (2014) Ocean of Trade: South Asian merchants, Africa and the Indian Ocean, c. 1750-1850. Cambridge: Cambridge University Press.

Mamdani, M. (1976) Politics and Class Formation in Uganda. New York NY: Monthly Review Press.

Mamdani, M. (2011) From Citizen to Refugee: Uganda Asians come to Britain. 2nd edition. Cape Town: Pambazuka Press.

Markovits, C. (2000) The Global World of Indian Merchants, 1750-1947: traders of Sind from Bukhara to Panama. Cambridge: Cambridge University Press.

Mehta, N. K. (1987) Dream Half-Expressed: an autobiography. Edited by R. Chhaya and translated by S. J. Pandya and V. M. Desai. Bombay: Vakil and Sons.

Metcalf, T. R. (2008) Imperial Connections: India and the Indian Ocean arena, 1860-1920. Berkeley and Los Angeles CA: University of California Press.

Mishra, S. (2011) Pilgrimage, Politics, Pestilence: the hajj from the Indian subcontinent 1860-1920. Delhi: Oxford University Press.

Moch, L. P. (1992) Moving Europeans: migration in Western Europe since 1650. Bloomington IN: Indiana University Press.

Mutabazi, S. N. (n.d.) 'Ugandans save Mabira forest from sugarcane plantation' in Global Nonviolent Action Database, Swarthmore College $<$ http://nvdatabase. swarthmore.edu/content/ugandans-save-mabira-forest-sugarcane-plantation2007>, accessed 11 May 2015.

Nair, S. (2001) 'Moving life histories: Gujarat, East Africa, and the Indian diaspora 1880-2000'. PhD thesis, University of Pennsylvania.

Nair, S. (2007) 'Tracing networks and revisiting expulsion'. Paper presented at 'The Interregional Circulation of Trade, Culture, and Labor', Third Annual South Asia Conference, Rutgers University, 8-10 November.

Nair, S. (2008) 'Shops and stations: rethinking privilege and power in British/ Indian East Africa' in J. C. Hawley (ed.), Africa in India, India in Africa: Indian Ocean cosmopolitanisms. Bloomington IN: Indiana University Press. 
Njoroge, J. (2011) 'I'm not interested in Mabira - Mehta', Daily Monitor, 3 September <http://www.monitor.co.ug/News/National/-/688334/1229602/-/ bjs08mz/-/index.html>, accessed 11 May 2015.

Obwona, M. B. (n.d.) 'Departed Asians Property Custodian Board divestiture notes'. Research Series 4. Kampala: Economic Policy Research <http://eprcug. org/pdf_files/researchseries/series4.pdf>, accessed 11 May 2015.

Ojwang, D. (2012) 'Indian Ocean trade and belonging in Nanji Kalidas Mehta's Dream Half-Expressed' in D. Ojwang (ed.), Reading Migration and Culture: the world of East African Indian literature. Basingstoke: Palgrave Macmillan.

Peach, C., V. Robinson, J. Maxted and J. Chance (1988) 'Immigration and ethnicity' in A. H. Halsey (ed.), British Social Trends since 1900. London: Macmillan.

Pearson, M. (2003) The Indian Ocean. New York NY: Routledge.

Rai, R. and P. Reeves (eds) (2009) The South Asian Diaspora: transnational networks and changing identities. London and New York NY: Routledge.

Ramchandani, R. R. (1980) India and Africa. New Delhi: Radiant.

Reeves, P. (2006) 'An entrepreneurial diaspora? Transnational space and India's international economic expansion' in P. Reeves and R. Rai (eds), The Encyclopedia of the Indian Diaspora. Singapore: Editions Didier Millet.

Reeves, P. and R. Rai (eds) (2006) The Encyclopedia of the Indian Diaspora. Singapore: Editions Didier Millet.

Roy, A. (2012) 'Uganda’s loss, Britain's gain', Mid-Day.com, 4 September <http:/l www.mid-day.com/articles/ugandas-loss-britains-gain/179926>, accessed 14 May 2015.

Rudner, D. (1994) Caste and Capitalism in Colonial India: the Nattukottai Chettiars. Berkeley CA: University of California Press.

Selva, M. (2005) 'Uganda: return of the exiles', Independent, 25 August <http:/l www.independent.co.uk/news/world/africa/uganda-return-of-the-exiles-308254. html\#>, accessed 19 May 2015.

Sheriff, A. and E. Ho (eds) (2014) The Indian Ocean: oceanic connections and the creation of new societies. London: Oxford University Press.

Short, P. (1972) “'Asians go home!” But where is home?', New York Times, 13 August.

Smith, M. P. and L. E. Guarnizo (eds) (1998) Transnationalism from Below. New Brunswick NJ: Transaction Publishers.

Smith, R. C. (1998) 'Transnational localities: community, technology and the politics of membership within the context of Mexico and U.S. migration' in M. P. Smith and L. E. Guarnizo (eds), Transnationalism from Below. New Brunswick NJ: Transaction Publishers.

Twaddle, M. (1975) Expulsion of a Minority: essays on Ugandan Asians. London: Athlone Press.

van der Veer, P. (1995) Nation and Migration: the politics of space in the South Asian diaspora. Philadelphia PA: University of Pennsylvania Press.

Vertovec, S. (1999) 'Conceiving and researching transnationalism', Ethnic and Racial Studies 22 (2): 447-62.

Weinraub, B. (1972) 'Prosperous Uganda Asians now despair', New York Times, 21 August.

Worth, S. E. (2017) In Defense of Reading. London: Rowman and Littlefield. 


\begin{abstract}
The distinctive migration history of Uganda's Indians allows us to rethink diaspora identities and memory in forming translocal communities. Settlement, citizenship and displacement created a postcolonial order of overlapping allegiances and multiple, mobile identities. 'Home' had been extended and thus connected to sites in India and East Africa, yet the 1972 expulsion called into question the ways in which Uganda's Indians recalled the very idea of home. While expulsion was a momentous crescendo to nineteenth- and early twentieth-century migrations, it did not put an end to the history of Uganda's Indians. This article focuses on the life histories of diverse Indian migrants: an industrialist's multi-local legacy, the post-expulsion return of Indians to two Ahmedabad (Gujarat, India) neighbourhoods, the repatriation of former residents back to Uganda in the 1980s and 1990s, and a brand-new generation of Indians coming to Uganda. By tracing these movements, I examine Indian migrants' articulations of identity, investment and interaction vis-à-vis East Africa and India. How do experiences of rejection and return factor into (multi)national loyalties, notions of home and diaspora identities? How does an autobiography, a built structure or a neighbourhood construct and complicate both memories of migration and a migrant community's identity? I place India and Africa on the same historical map, and, by doing so, offer a way to include Indians in the framework of African political economy and society.
\end{abstract}

\title{
Résumé
}

L'histoire migratoire particulière des Indiens d'Ouganda nous permet de repenser les identités et la mémoire de la diaspora dans la formation de communautés translocales. L'installation, la citoyenneté et le déplacement ont créé un ordre postcolonial d'allégeances imbriquées et d'identités mobiles multiples. Malgré l'extension de la notion de pays d'appartenance ("Home ») et par là-même son lien à des lieux en Inde et en Afrique de l'Est, l'expulsion de 1972 a remis en question la manière dont les Indiens d'Ouganda se sont rappelés l'idée-même de pays d'appartenance. Cette expulsion a marqué un crescendo important dans les migrations du dix-neuvième siècle et du début du vingtième, mais elle n'a pas mis fin à l'histoire des Indiens d'Ouganda. Cet article met l'accent sur les récits de vie de migrants indiens divers : l'héritage multilocal d'un industrialiste, le retour d'Indiens dans deux quartiers d'Ahmedabad (Gujarat, Inde) après leur expulsion, le retour en Ouganda d'anciens résidents rapatriés dans les années 1980 et 1990, et une toute nouvelle génération d'Indiens arrivés en Ouganda. En retraçant ces mouvements, l'auteur examine les articulations d'identité, d'investissement et d'interaction des migrants indiens vis-à-vis de l'Afrique de l'Est et de l'Inde. Comment ces expériences de rejet et de retour s'intègrent-elles dans les loyautés (multi)nationales, les notions de pays d'appartenance et les identités diasporiques? Comment une autobiographie, une structure construite ou un quartier peut-il construire et compliquer les mémoires de migration et l'identité d'une communauté de migrants ? L'auteur place l'Inde et l'Afrique sur la même carte historique et, ce faisant, offre un moyen d'inclure les Indiens dans le cadre de l'économie politique et de la société africaines. 